\title{
DETERMINAN FINANCING TO DEPOSIT RATIO BANK UMUM SYARIAH DI INDONESIA
}

PERIODE 2012 - 2015 1)

\author{
Didit Prakoso \\ Program Studi Ekonomi Islam-Fakultas Ekonomi dan Bisnis-Universitas Airlangga \\ Email: didit.prakoso-12@feb.unair.ac.id \\ Achsania Hendratmi \\ Departemen Ekonomi Syariah-Fakultas Ekonomi dan Bisnis-Universitas Airlangga \\ Email: nia_rachmadi@gmail.com
}

\begin{abstract}
:
The research aimed to know the influence of Capital Adequacy Ratio (CAR), Return on Assets (ROA) and Size of the Financing to Deposit Ratio (FDR) Islamic Banks in Indonesia by using 11 Islamic Banks registered at Bank Indonesia the period 2012 to 2015 as samples. The research used a quantitative approach method. The analysis technique used multiple linear regression analysis and the equation is $Y=0,330+1,294$ (CAR) - 5,931 (ROA) + 0,028 (Size). Based on the result of t-test (partial), CAR, ROA and Size significantly affects of FDR with the results of each 6,727, -2,831, 2,564. While the results of f-test (simultant) showed that CAR, $R O A$ and Size significant effect on of FDR with a significance value 0.000 . the coefficient of determination shows the value of R-Square $\left(R^{2}\right)$ of $54.0 \%$. while the remains of $46 \%$ was explained by other variables outside the model.
\end{abstract}

Keywords: Capital Adequacy Ratio (CAR), Return on Assets (ROA), Size, Financing to Deposit Ratio (FDR), Islamic Banks

\section{PENDAHULUAN}

Bank Syariah adalah suatu lembaga keuangan yang berfungsi sebagai perantara (Intermediary) bagi pihak yang berkelebihan dana dengan pihak yang kekurangan dana untuk kegiatan usaha dan kegiatan lainnya sesuai dengan hukum Islam (Ali, 2008).

Sesuai dengan Undang-Undang Nomor 7 Tahun 1992 tentang Perbankan sebagaimana telah diubah dengan Undang-Undang Nomor 10 Tahun 1998, Likuiditas adalah salah satu faktor dalam menilai kesehatan bank dan merupakan faktor penting dalam industri perbankan untuk meningkatkan kepercayaan publik.

Dalam prakteknya, salah satu tujuan utama dari menjaga kesehatan bank adalah menjaga saldo aset-kewajiban. kegiatan pendanaan dan pembiayaan; prakiraan permintaan pendanaan dan pembiayaan; dan mempertahankan kapasitas yang cukup (cadangan) untuk memenuhi kewajiban dengan dana pihak ketiga (Ismal, 2010:147).

Taswan (2010:245) menyatakan bahwa semakin besar dana mengendap di kas semakin likuid bank tersebut. Sebaliknya bila didominasi aset pada aktiva jangka panjang, maka pendapatan bank akan tinggi namun likuiditasnya rendah. Dimana di satu sisi usaha bank yang utama adalah memasarkan dan atau memutar vang para nasabahnya untuk pemasaran vangnya dan juga berusaha untuk tidak membiarkan vang menganggur (idle money).

Oleh karena itu, bank harus mengelola

1) Jurnal ini merupakan bagian dari skripsi yang ditulis oleh [Didit Prakoso; 041211433084] yang diuji pada tanggal 08 Februari 2017 
Bank Syariah wajib menjalankan fungsi intermediary-nya dengan sebaikbaiknya sebagai penghimpun dana dari nasabah yang kelebihan dana serta menyalurkan dana bagi nasabah yang membutuhkan dana. Untuk melihat bagaimana bagaimana suatu Bank Syariah dapat menjalankan fungsi intermediary-nya dengan baik salah satu rasio yang dapat digunakan yaitu rasio FDR (Financing to Deposit Ratio).

Menurut kasmir (2012:221) rasio FDR adalah rasio yang digunakan untuk mengukur komposisi jumlah kredit yang diberikan dibandingkan dengan jumlah dana masyarakat dan modal sendiri yang digunakan. FDR yang tinggi menggambarkan kemampuan penyaluran dana yang baik. Maksimal FDR yang diperkenankan oleh $\mathrm{BI}$ bagi bank umum dan unit usaha syariah adalah sebesar $110 \%$.

Sebagai faktor penunjang FDR lembaga keuangan syariah, maka peran Dana Pihak Ketiga (DPK) menjadi penting. Menurut Rivai (2007:57) kegiatan bank syariah menghimpun dana (Dana pihak ketiga) adalah dana yang berasal dari masyarakat luas. Pada sebagian besar atau setiap bank, dana masyarakat ini umumnya merupakan dana terbesar yang dimiliki. Dana pihak ketiga yaitu berupa Giro, Tabungan, Deposito dan atau bentuk lainnya yang dipersamakan dengan itu.

Setelah Dana Pihak Ketiga (DPK) telah dikumpulkan oleh bank, dan sesuai dengan fungsi intermediary-nya maka bank berkewajiban menyalurkan dana tersebut untuk pembiayaan. Dalam hal ini, bank harus mempersiapkan strategi penggunaan dana yang dihimpunnya sesuai dengan rencana alokasi berdasarkan kebijakan yang telah ditentukan.

Aktiva juga memiliki potensi manfaat di masa yang akan datang, potensi manfaat tersebut bisa dalam bentuk hal hal yang produktif yang bisa menghasilkan kas atau setara kas. Menurut Brigham dan Joel (2001) Aktiva adalah kekayaan (sumber daya) yang dimiliki oleh entitas bisnis yang bisa diukur secara jelas menggunakan satuan vang serta sistem pengurutannya berdasar pada seberapa cepat perubahannya dikonversi menjadi satuan uang kas terutama pada aktiva lancar. Maka dari itu aktiva juga menjadi perhatian penting apabila nasabah dalam melakukan penarikan dana DPK secara tiba-tiba dan Bank Syariah tersebut tidak mempunyai dana yang cukup untuk memenuhi permintaan nasabah. Maka dari itu perlu adanya pencarian dana dari akun aktiva terutama pada aktiva lancar.

Modal bank juga dapat digunakan untuk menjaga kemungkinan timbulnya risiko, diantaranya risiko yang timbul dari pembiayaan itu sendiri. Untuk menanggulangi risiko yang mungkin terjadi maka harus menyediakan penyediaan modal minimum. Menurut Abdillah, dkk (2016:142) Rasio dalam menentukan modal bank syariah dapat 
dilihat dengan menggunakan variabel Capital Adequacy Ratio (CAR)

Aktifitas dalam melakukan kegiatan bisnis, selalu mengharapkan adanya keuntungan, keuntungan yang diperoleh dalam sistem operasional Syariah adalah bagi hasil atas kegiatan pembiayaan kepada nasabah atau masyarakat anggota secara adil (Ervina,2015:8). Menurut Abdillah dkk. (2016:142) Profitabilitas bank dapat diukur dengan Return on Assets (ROA). Semakin besar ROA suatu bank, semakin besar pula tingkat keuntungan yang dicapai bank tersebut dan semakin baik pula posisi bank tersebut dari segi penggunaan aset (Utari, 2011).

Oleh karena itu perlu diteliti "Determinan Financing to Deposit Ratio Bank Umum Syariah Di Indonesia" Penelitian ini bertujuan untuk Menguji Apakah Capital Adequacy Ratio (CAR), Return On Assets (ROA), Dan Size Secara Parsial maupun simultan berpengaruh Terhadap Financing To Deposit Ratio Bank Umum Syariah Di Indonesia.

\section{LANDASAN TEORI}

Menurut undang-undang Nomor 21 Tahun 2008 tentang perbankan syariah, Bank Syariah didefinisikan sebagai bank yang menjalankan kegiatan usahanya berdasarkan prinsip syariah dan menurut jenisnya terdiri atas Bank Umum Syariah dan Bank Pembiayaan Rakyat Syariah (Ismail, 2011:33). Selain itu, Bank Syari'ah bisa disebut Islamic banking atau interest free banking, yaitu suatu sistem perbankan dalam pelaksanaan operasional tidak menggunakan sistem bunga (riba), spekulasi (maisir), dan ketidakpastian atau ketidak jelasan (gharar) (Ali, 2008).

Riba diharamkan dengan dikaitkan kepada suatu tambahan yang berlipat ganda. Seperti pada firman Allah SWT QS. Ali-Imran:130

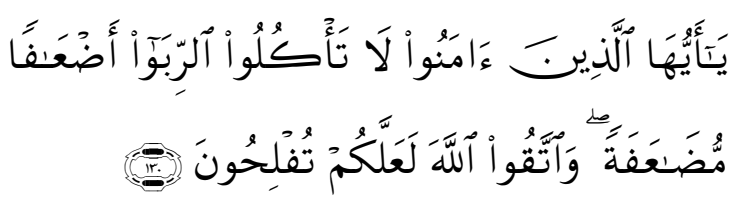

ya- ayyuha-allazina amanu' la' ta'kulú alrriba' adh'afan muda'afatan waittaqu' allaha la'allakum tuflihuña

Artinya: "130. Hai orang-orang yang beriman, janganlah kamu memakan Riba dengan berlipat ganda[228] dan bertakwalah kamu kepada Allah supaya kamu mendapat keberuntungan."

Bank Syariah adalah suatu lembaga keuangan yang berfungsi sebagai perantara (intermediary) bagi pihak yang berkelebihan dana dengan pihak yang kekurangan dana untuk kegiatan usaha dan kegiatan lainnya sesuai dengan hukum Islam. Selain itu, bank syari'ah bisa disebut Islamic banking atau interest free banking, yaitu suatu sistem perbankan dalam pelaksanaan operasional tidak menggunakan sistem bunga (riba), spekulasi (maisir), dan ketidakpastian atau ketidak jelasan (gharar). (Ali, 2008). Untuk pengukuran Bank Syariah dalam menjalankan fungsi intermediary-nya peneliti menggunakan rasio Financing to Deposit Ratio (FDR)

Financing to Deposit Ratio (FDR) merupakan rasio yang menyatakan seberapa jauh kemampuan bank dalam 
Prakoso, et al/Jurnal Ekonomi Syariah Teori dan Terapan Vol. 4 No. 11 November 2017: 860-874; DETERMINAN FINANCING TO DEPOSIT RATIO BANK UMUM SYARIAH DI INDONESIA PERIODE 2012 - 2015

membayar kembali penarikan dana yang dilakukan dengan mengandalkan dana pihak ketiga yang diberikan sebagai sumber pembiayaan. Semakin tinggi FDR maka penyaluran dana (pembiayaan) oleh bank akan meningkat (Munandar 2009).

Menurut Dendawijaya (2005:121) Capital Adequacy Ratio (CAR) adalah Rasio yang memperlihatkan seberapa jauh seluruh aktiva bank yang mengandung risiko (kredit, penyertaan, surat berharga, tagihan pada bank lain) ikut dibiayai dari dana modal sendiri bank disamping memperoleh dana - dana dari sumber - sumber di luar bank, seperti dana dari masyarakat, pinjaman, dan lain - lain. CAR merupakan indikator terhadap kemampuan bank untuk menutupi penurunan aktivanya sebagai akibat dari kerugian - kerugian bank yang di sebabkan oleh aktiva yang berisiko.

Rentabilitas (earnings) adalah kemampuan perusahaan dalam menghasilkan laba yang diukur dengan Return On Asset (ROA). Menurut kasmir (2012:201) ROA adalah rasio yang menunjukkan hasil (return) atas jumlah aktiva yang digunakan dalam perusahaan yang menunjukkan besarnya laba yang diperoleh bank terhadap ratarata total aset dimana rata-rata total aset diperoleh dari jumlah aset awal periode dan akhir periode dibagi dua.

Menurut Brigham dan Joel (2001) Aktiva adalah kekayaan (sumber daya) yang dimiliki oleh entitas bisnis yang bisa diukur secara jelas menggunakan satuan vang serta sistem pengurutannya berdasar pada seberapa cepat perubahannya dikonversi menjadi satuan vang kas terutama pada aktiva lancar.

\section{Hubungan CAR terhadap FDR}

Bila tingkat kecukupan modal bank baik, maka masyarakat akan tertarik untuk mengambil kredit, dan pihak bank memiliki dana cadangan jika sewaktuwaktu terjadi masalah kredit macet. Pemberian kredit bank pada masyarakat diwakili dengan rasio FDR. Bank yang memiliki kecukupan modal yang tinggi maka akan meningkatkan kepercayaan diri dalam menyalurkan kredit (Parinsi, 2013:23)

Penelitian yang dilakukan oleh Parinsi (2013) bahwa CAR berpengaruh positif signifikan terhadap FDR bank BUMN di Indonesia. Sedangkan penelitian Ervina (2015) yang menyatakan bahwa Capital Adequacy Ratio (CAR) berpengaruh terhadap FDR pada KJKS-BMT. Hal yang sama dibuktikan oleh Edo dan $\mathrm{Ni}$ Luh (2014) yang menyatakan bahwa Capital Adequacy Ratio (CAR) berpengaruh terhadap Loan to Deposit Ratio.

\section{Hubungan ROA terhadap FDR}

Return On Assets (ROA) adalah indikator yang akan menunjukkan bahwa apabila rasio ini meningkat maka aktiva bank telah digunakan dengan optimal untuk memperoleh pendapatan sehingga diperkirakan ROA dan kredit memiliki hubungan yang signfikan. Return On Assets (ROA) digunakan untuk mengukur kemampuan manajemen bank dalam memperoleh keuntungan (laba) secara 
keseluruhan (Dendawijaya,2009). Semakin besar Return On Assets (ROA) suatu bank semakin besar pula tingkat keuntungan yang dicapai bank tersebut dengan laba yang besar maka suatu bank dapat menyalurkan kredit lebih banyak, sejalan dengan kredit yang meningkat maka akan meningkatkan FDR itu sendiri.

Penelitian yang dilakukan oleh Solekah (2015) yang menyatakan bahwa Return On Assets (ROA) berpengaruh negatif dan signifikan terhadap Financing to Deposit Ratio (FDR). Hal tersebut juga dibuktikan oleh Moussa (2015) bahwa ROA berpengaruh negatif signifikan terhadap Financing to Deposit Ratio. Sedangkan penelitian oleh Ervina (2015) juga menyatakan bahwa Return On Assets (ROA) berpengaruh negatif signifikan terhadap Financing to Deposit Ratio (FDR).

\section{Hubungan Size terhadap FDR}

Struktur aset sangat berpengaruh terhadap besarnya laba yang dihasilkan. Apabila porsi terbesar aset adalah piutang dari penyaluran kredit, maka piutang dari penyaluran kredit (kategori lancar atau performing loans) akan meningkatkan pendapatan yang diterima karena performing loans ini merupakan income-generating asset dalam bentuk pendapatan operasional (Wild dkk. 2010).

Penelitian yang dilakukan oleh Santoso dan Tekad (2012) yang membuktikan juga bahwa variabel size berpengaruh positif dan signifikan terhadap Financing to Deposit Ratio (FDR). Sedangkan penelitian Bramantya (2015) yang menyatakan bahwa Size berpengaruh positif terhadap Financing to Deposit Ratio (FDR) pada Bank Umum yang terdaftar di Bursa Efek Indonesia.

\section{HIPOTESIS}

$\mathrm{Hl}$ : CAR Secara Parsial Berpengaruh Positif Signifikan Terhadap FDR

H2: ROA Secara Parsial Berpengaruh Negatif Signifikan Terhadap FDR

H3: Size Secara Parsial Berpengaruh Positif Signifikan Terhadap FDR

H4: Jumlah CAR, ROA, Dan size Berpengaruh Secara Simultan Terhadap FDR

\section{MODEL ANALISIS}

Model analisis yang digunakan dapat di formulasikan sebagai berikut:

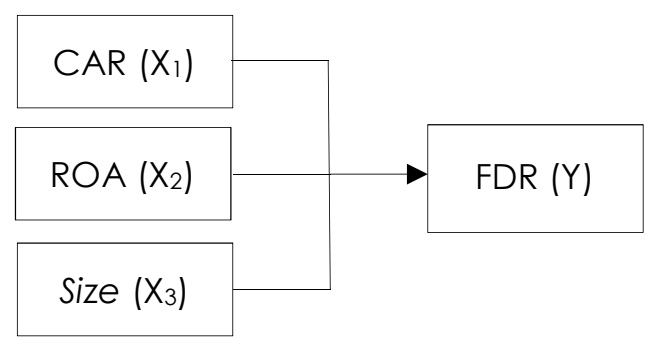

Gambar 2.1

Model Analisis

Persamaannya adalah:

$Y=\beta+\beta 1 \times 1-\beta 2 X 2+\beta 3 \times 3+\beta 3 \times 3+e$.

Dimana :

$\mathrm{Y}=$ Financing to Deposit Ratio (FDR)

B = Konstanta

$B_{1}-B_{3}=$ Koefisien regresi

$X_{1}=$ Capital Adequacy Ratio (CAR)

$\mathrm{X}_{2}=$ Return On Assets (ROA)

$X_{3}=$ Size

$\mathrm{e} \quad=$ error terms

\section{METODE PENELITIAN}

\section{PENDEKATAN PENELITIAN}

Dalam penelitian ini menggunakan rancangan penelitian berdasarkan pendekatan penelitian kuantitatif. 


\section{IDENTIFIKASI VARIABEL}

Variabel yang terdapat dalam judul penelitian ini terdapat 2 variabel yaitu :

1. Variabel Bebas / Independent Variable

$\mathrm{X}_{1}$ : Capital Adequacy Ratio (CAR)

$\mathrm{X}_{2}$ : Return On Asset (ROA)

$\mathrm{X}_{3}$ : Size

2. Variabel Terikat / Dependent Variable

Y: Financing to Deposit Ratio (FDR) Bank Umum Syariah Di Indonesia.

\section{DEFINISI OPERASIONAL}

1. Capital Adequacy Ratio (CAR)

Dalam hal ini untuk mengukur rasio Capital Adequacy Ratio (CAR) menurut Kasmir (2012) menggunakan rumus:

$C A R=\frac{\text { Modal }}{\text { ATMR }} \times 100 \%$

2. Return On Assets (ROA)

Rumus yang digunakan untuk mencari rasio Return On Asset Menurut Kasmir (2012) adalah sebagai berikut :

ROA $=\frac{\text { Laba Sebelum Pajak }}{\text { Rata-Rata Total Assets }} \times 100 \%$

3. Size

Dalam hal ini untuk mengukur rasio Size

of Bank menurut Moussa (2015) menggunakan rumus :

Size $=\ln$ Total Asset

4. Financing to Deposit Ratio (FDR)

Rumus perhitungan FDR Menurut Kasmir (2012) adalah sebagai berikut:

$F D R=\frac{\text { Total Financing }}{\text { Total Deposit }} \times 100 \%$

\section{POPULASI DAN SAMPEL}

Populasi dalam penelitian ini adalah Industri Bank Syariah Di Indonesia. Sampel dalam penelitian ini adalah 11 Bank Umum Syariah Di Indonesia yang telah memenuhi kriteria sebagai sampel.
Dengan periode 4 tahun terakhir tiap variabel dengan periode Tahun 2012 hingga Tahun 2015, sehingga totalnya 44 sampel.

\section{JENIS DAN SUMBER DATA}

Jenis data yang digunakan dalam penelitian ini adalah data sekunder. Data sekunder dalam penelitian ini adalah data sekunder yang diambil dari website resmi Bank Umum Syariah yang diterbitkan periode tahunan maupun triwulanan mulai dari tahun 2012 sampai dengan tahun 2015. Data pada penelitian ini termasuk dalam time series dengan skala rasio.

\section{TEKNIK ANALISIS}

Teknik analisis yang digunakan adalah teknik analisis regresi linier berganda untuk melihat hubungan antara satu variabel terikar dengan lebih dari satu variabel bebas. Distribusi Lag perlu dilakukan untuk mengetahui pengaruh variabel independen $X$ pada periode tahun sebelumnya dapat mempengaruhi variabel dependen $Y$ pada tahun tertentu.

\section{HASIL DAN PEMBAHASAN}

\section{Analisis Deskriptif}

Analisis statistik deskrpitif dalam penelitian ini bertujuan untuk mengartikan gambaran mengenai variabel-variabel yang digunakan baik variabel independen maupun variabel independen. Berdasarkan hasil penelitian dapat diketahui nilai minimum, maksimum dan rata-rata masing-masing variabel dari Bank Umum Syariah. 
Tabel 4.1

Analisis Deskriptif

\begin{tabular}{|l|r|r|r|r|c|}
\hline & $\mathrm{N}$ & $\begin{array}{c}\text { Mini } \\
\text { mum }\end{array}$ & $\begin{array}{c}\text { Maxi } \\
\text { mum }\end{array}$ & $\begin{array}{c}\text { Mea } \\
\mathrm{n}\end{array}$ & $\begin{array}{c}\text { Std. } \\
\text { Deviati } \\
\text { on }\end{array}$ \\
\hline FDR & 44 &, 461 & 1,977 & 9736 &, 229529 \\
8 & & & \\
Lag_CAR & 44 &, 111 &, 734 & 2378 &, 161869 \\
0 & & & \\
Lag_ROA & 44 &,- 019 &, 069 & 0139 &, 014478 \\
Lag_SIZE & 44 & 9,407 & 18,02 & 14,68 & 2,39371 \\
Valid N & 44 & & 0 & 834 & 4 \\
(listwise) & & & & & \\
\hline
\end{tabular}

Sumber : Hasil Uji SPSS 18 (Data Diolah)

Uji Analisis Regresi Linier Berganda

Analisis regresi linier berganda merupakan model analisis untuk mengetahui Capital Adequacy Ratio (CAR), Return On Assets (ROA), dan Size terhadap Financing to Deposit Ratio (FDR) Bank Umum Syariah. Dalam hasil olah regresi linier berganda terdapat persamaan yang menunjukan model regresi penelitian ini. Berikut persamaan regersi linear berganda yang diperoleh dari hasil olahan SPSS 18 yang tercantum dalam tabel 4.2

Dengan asumsi data terdistribusi Lag :

a) Variabel Dependen : Y ( $t$ )

b) Variabel Independen: X1, X2, X3 (t-1)

Tabel 4.2

Analisis Regresi Linier Berganda

\begin{tabular}{|c|c|c|c|}
\hline \multirow[t]{2}{*}{ Model } & \multicolumn{2}{|c|}{$\begin{array}{c}\text { Unstandardized } \\
\text { Coefficients }\end{array}$} & \multirow[b]{2}{*}{ Sig. } \\
\hline & B & Std. Error & \\
\hline 1 (Constant) & ,330 & , 177 & ,069 \\
\hline Lag_CAR & 1,294 & , 192 &, 000 \\
\hline Lag_ROA & $-5,931$ & 2,095 & ,007 \\
\hline Lag_SIZE & 028 & 011 &, 014 \\
\hline
\end{tabular}

a. Dependent Variable: FDR

Sumber : Hasil Uji SPSS 18 (Data Diolah)

Berdasarkan hasil pengujian analisis regresi linear berganda pada tabel 4.2 diatas, maka didapatkan persamaan regresi sebagai berikut:

$Y=0,330+1,294 X_{1}-5,931 X_{2}+0,028 X_{3}+e$

Dimana variabel independen adalah Capital Adequacy Ratio (CAR), Return On Assets (ROA), dan Size. Sedangkan variabel dependennya adalah Financing to Deposit Ratio (FDR). Dari persamaan regresi linear berganda yang tertera pada tabel 4.5 maka dapat dijelaskan sebagai berikut:

1. Nilai konstanta sebesar 0,330 menunjukan apabila variabel Capital Adequacy Ratio (CAR), Return On Assets (ROA), dan Size besarnya nol atau konstan, maka Financing to Deposit Ratio (FDR) adalah sebesar 0,330.

2. Koefisien Capital Adequacy Ratio (CAR) sebesar 1.294, hal ini menunjukan bahwa apabial Capital Adequacy Ratio (CAR) meningkat satu satuan maka akan mempengaruhi Financing to Deposit Ratio (FDR) sebesar 1.294 dengan asumsi variabel lain konstan.

3. Koefisien Return On Assets (ROA) sebesar -5.931 hal ini menunjukan bahwa Return On Assets (ROA) meningkat satu satuan maka akan mempengaruhi Financing to Deposit Ratio (FDR) sebesar 5.931 dengan asumsi variabel lain konstan. 4. Koefisien Size sebesar 0.028, hal ini menunjukan bahwa apabial size meningkat satu satuan maka akan mempengaruhi Financing to Deposit Ratio (FDR) sebesar 0.028 dengan asumsi variabel lain konstan

\section{Koefisien Determinasi}


Prakoso, et al/Jurnal Ekonomi Syariah Teori dan Terapan Vol. 4 No. 11 November 2017: 860-874; DETERMINAN FINANCING TO DEPOSIT RATIO BANK UMUM SYARIAH DI INDONESIA PERIODE 2012 - 2015

Koefisien determinasi digunakan untuk mengukur variasi bank umum syariah dependen yang dapat dijelaskan oleh variabel independen secara simultan dan nilai koefiesien determinasi berkisar 0 sampai dengan 1. Semakin besar koefisien determinasi yaitu semakin mendekati satu, maka semakin baik variabel independen menjelaskan variasi perubahan pada variabel dependen.

Tabel 4.3 Koefisien Determinasi

\begin{tabular}{|c|c|c|c|c|c|}
\hline $\begin{array}{l}\text { Mo } \\
\text { del }\end{array}$ & $\mathrm{R}$ & $\begin{array}{c}\mathrm{R} \\
\text { Squar } \\
\mathrm{e}\end{array}$ & $\begin{array}{l}\text { Adjusted } \\
\text { R Square }\end{array}$ & $\begin{array}{l}\text { Std. Error } \\
\text { of the } \\
\text { Estimate }\end{array}$ & $\begin{array}{l}\text { Durbin- } \\
\text { Watson }\end{array}$ \\
\hline 1 &, $735^{a}$ &, 540 &, 506 & , 161372 & 1,721 \\
\hline
\end{tabular}

a. Predictors: (Constant), Lag_SIZE, Lag_ROA, Lag_CAR

b. Dependent Variable: FDR

Sumber : Hasil Uji SPSS 18 (Data Diolah)

Berdasarkan hasil pada Tabel 4.3 dalam penelitian ini hasil koefisien determinasi yang ditunjukan oleh R-square (R2) menunjukan nilai 0.540 atau sebesar $54.0 \%$ yang memiliki arti Capital Adequacy Ratio (CAR), Return On Assets (ROA), dan Size dapat menjelaskan variabel dependen sebesar $54 \%$ sedangkan sisanya sebesar $46 \%$ dijelaskan oleh variabel lain yang tidak dimasukan ke dalam model regeresi.

\section{Uji Hipotesis}

\section{Uji T}

Uji $†$ bertujuan untuk menganalisis tingkat signifikasi pengaruh variabel independen terhadap variabel dependen secara parsial. Untuk melihat pengaruh signifikan secara parsial maka nilai signifikansi yang ditentukan adalah kurang dari 0.05 dan membandingkan † hitung dengan $\uparrow$ tabel, apabil $\dagger$ hitung $>\dagger$ tabel maka variabel independen memiliki pengaruh signifikan secara parsial terhadap Financing to Deposit Ratio (FDR).

Tabel 4.4

Hasil Uji T

\begin{tabular}{|ll|r|r|}
\hline \multicolumn{2}{|l|}{ Model } & \multicolumn{1}{c|}{$\dagger$} & \multicolumn{1}{c|}{ Sig. } \\
\hline 1 & (Constant) & 1,868 &, 069 \\
& Lag_CAR & 6,727 &, 000 \\
& Lag_ROA & $-2,831$ &, 007 \\
& Lag_SIZE & 2,564 &, 014 \\
\hline
\end{tabular}

Sumber : Hasil Uji SPSS 18 (Data Diolah)

Berdasarkan hasil Tabel 4.4 maka dapat dibuktikan pengujian hipotesis setiap variabel indenpenden terhadap variabel dependen yang mana sebagai berikut :

1. Nilai Uji T Variabel CAR adalah 6.727 dengan tingkat signifikansi sebesar 0.000 . Nilai $t$ hitung yang ditunjukkan oleh variabel CAR sebesar 6.727 dan nilai $\dagger$ tabel sebesar 2.021075 (Lampiran Tabel T), maka dapat disimpulkan $\mathrm{H} 1$ diterima, bahwa CAR berpengaruh signifikan positif terhadap FDR Bank Umum Syariah. Nilai positif ditunjukkan dengan nilai koefisien yang positif pada variabel CAR (X1)

2. Nilai Uji $T$ Variabel ROA adalah -2.831 dengan tingkat signifikansi sebesar 0.007 . Nilai $\dagger$ hitung yang ditunjukkan oleh variabel ROA sebesar -2.831 dan nilai $\dagger$ tabel sebesar 2.021075 (Lampiran Tabel T), maka dapat disimpulkan H2 diterima, bahwa ROA berpengaruh signifikan negatif terhadap FDR Bank Umum Syariah. Nilai negatif ditunjukkan dengan nilai 
koefisien yang positif pada variabel ROA (X2)

3. Nilai Uji T Variabel SIZE adalah 2.564 dengan tingkat signifikansi sebesar 0.014 . Nilai $\dagger$ hitung yang ditunjukkan oleh variabel SIZE sebesar 2.564 dan nilai t tabel sebesar 2.021075 (Lampiran Tabel T), maka dapat disimpulkan $\mathrm{Hl}$ diterima, bahwa SIZE berpengaruh signifikan positif terhadap FDR Bank Umum Syariah. Nilai positif ditunjukkan dengan nilai koefisien yang positif pada variabel SIZE (X3)

Uji $F$

Uji $F$ digunakan untuk mengetahui pengaruh variabel independen terhadap variabel dependen secara bersama-sama atau simultan. Sesuai dengan langkahlangkah yang dilakukan dalam melakukan uji $F$, untuk mengetahui signifikansi diketahui melalui F-hitung > Ftabel dengan $a=5 \%$ sehingga variabel independen berpengaruh signifikan terhadap variabel dependen secara simultan.

Tabel 4.5

Hasil Uji F

ANOVA ${ }^{b}$

\begin{tabular}{|c|c|c|c|c|c|}
\hline Model & $\begin{array}{c}\text { Sum of } \\
\text { Square } \\
\text { s }\end{array}$ & $\mathrm{df}$ & $\begin{array}{l}\text { Mean } \\
\text { Square }\end{array}$ & $F$ & Sig. \\
\hline $\begin{array}{ll}1 & \text { Regre } \\
\text { ssion } \\
\text { Residu } \\
\text { al } \\
\text { Total }\end{array}$ & $\begin{array}{l}1,224 \\
1,042 \\
2,265\end{array}$ & $\begin{array}{r}3 \\
40 \\
43\end{array}$ & $\begin{array}{l}.408 \\
.026\end{array}$ & $\begin{array}{r}15,6 \\
64\end{array}$ & $\begin{array}{r}, 000 \\
a\end{array}$ \\
\hline
\end{tabular}

a. Predictors: (Constant), SIZE, ROA, CAR

b. Dependent Variable: FDR

Sumber : Hasil Uji SPSS 18 (Data Diolah)

Berdasarkan Tabel 4.5 diperoleh $\mathrm{F}$ Hitung penelitian ini sebesar 15.664 dengan nilai signifikansinya 0.000 . F-tabel dengan df penyebut 41 dan df pembilang 3, nilai $F$ tabel adalah 2.838745. Hasil tersebut menunjukkan bahwa $F$ hitung $15.664>2.838745$ F Tabel. Maka dapat dinyatakan $\mathrm{H} 1$ diterima karena $\mathrm{F}$ hitung lebih besar dari $F$ tabel dengan signifikansi dalam penelitian ini sebesar 0.000 kurang dari 0.05. Hasil Uji F ini menyatakan bahwa HI diterima sehingga kesimpulannya variabel CAR, ROA dan Size secara simultan berpengaruh signifikan positif terhadap FDR Bank Umum Syariah di Indonesia.

\section{Uji Asumsi Klasik}

\section{Uji Multikolinieritas}

Uji Multikolinearitas digunakan untuk mengetahui adanya hubungan atau korelasi antar masing-masing variabel dalam penelitian ini. Uji ini menunjukan adanya hubungan linear yang sempurna atau pasti antar variabel. Untuk mendeteksi adanya gejala multikolinearitas pada model regresi dapat dilihat dari nilai tolerance dan variance inflation factor (VIF). Gejala multikolinieritas tidak terjadi apabila niali tolerance penelitian $>0,1$ dan nilai variance inflation factor < 10. Hasil pengujian multikolinearitas dalam penelitian ini ditunjukan dalam tabel 4.6 berikut :

Tabel 4.6

Hasil Uji Multikolinieritas

\begin{tabular}{|l|r|r|l|}
\hline \multirow{2}{*}{ Variabel } & \multicolumn{2}{|c|}{$\begin{array}{c}\text { Colliniearity } \\
\text { Statistic }\end{array}$} & \multirow{2}{*}{ Keterangan } \\
\cline { 2 - 3 } & $\begin{array}{r}\text { Toleran } \\
\text { ce }\end{array}$ & VIF & \\
\hline $\begin{array}{l}\text { FDR } \\
\text { (Constant) } \\
\text { Lag_CAR }\end{array}$ &, 625 & $\begin{array}{r}1,60 \\
1\end{array}$ & $\begin{array}{l}\text { Bebas } \\
\text { Multikolinearita }\end{array}$ \\
\hline
\end{tabular}




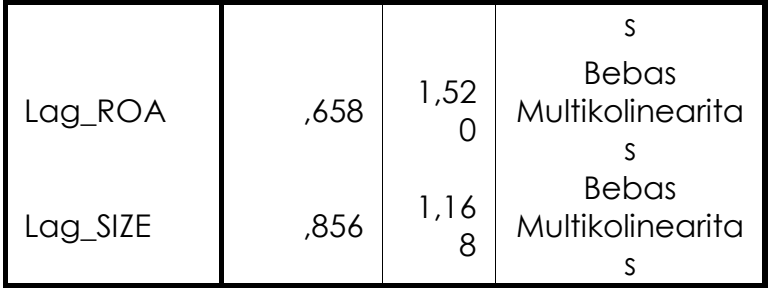

Sumber : Hasil Uji SPSS 18 (Data Diolah)

Tabel 4.6 menunjukkan hasil Uji Multikolinearitas, berdasarkan hasil Uji Multikolinearitas tersebut bahwa setiap variabel dalam penelitian ini yaitu Capital Adequacy Ratio (CAR), Return On Assets (ROA), dan Size mempunyai nilai Tolerance $>0,1$ dan $\mathrm{VIF}<10$. Hal ini dapat disimpulkan bahwa semua variabel dalam penelitian ini tidak terjadi Multikoliniearitas atau bebas Multikolinearitas.

\section{Uji Heterokedastisitas}

Pengujian digunakan untuk menguji ada tidaknya hubungan antara variabel terikat dengan variabel bebas. Apabila varian dari residual pengamatan ke pengamatan lain tetap maka disebut dengan homokedastistas. Cara mendeteksi ada tidaknya heterokedastistas dapat dilakukan dengan cara melakukan uji scatterplot. Hasil uji heterokedastistas dalam penelitian ini terdapat pada Gambar 4.1 berikut.

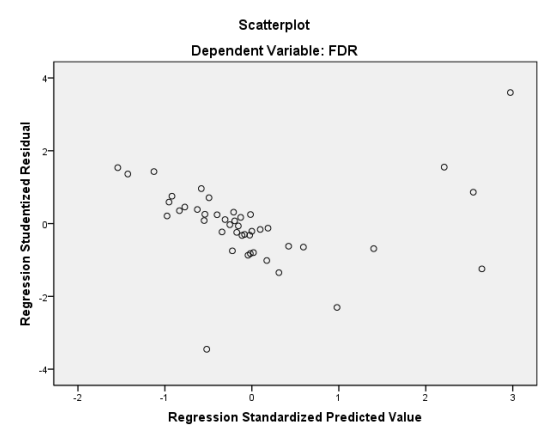

Sumber : Hasil Uji SPSS 18 (Data Diolah)

Gambar 4.1

Hasil Uji Heterokedastisitas
Bedasarkan gambar 4.1 diagram scatterplot diatas menunjukan bahwa titiktitik menyebar tidak mengumpul dan tidak memebentuk pola yang khas. Hal ini dapat diartikan bahwa terjadi gejala homokedastistas atau tidak terjadi heterokedastistas yang menunjukan tidak terjadi hubungan antara variabel independen dan variabel dependen. Dalam penelitian ini menyatakan bahwa model regresi terbebas dari gejala Heterokedastistas.

\section{Uji Autokorelasi}

Autokorelasi adalah korelasi yang terjadi diantara anggota observasi yang terletak berderetan, biasanya terjadi pada data timeseries. Untuk mendeteksi autokorelasi dapat dilakukan dengan uji DurbinWatson (DW) dengan ketentuan sebagi berikut:

a. 1,65 < DW < 2,35 maka tidak ada autokorelasi

b. $1,21<\mathrm{DW}<1,65$ atau $2,35<\mathrm{DW}<2,79$ maka tidak dapat disimpulkan

c. $D W<1,21$ atau $D W>2,79$ maka terjadi autokorelasi (Sujianto, 2009:79)

Tabel 4.7

Uji Durbin-Watson

\begin{tabular}{|c|c|c|c|c|c|}
\hline $\begin{array}{l}\text { Mo } \\
\text { del }\end{array}$ & $R$ & $\begin{array}{c}\mathrm{R} \\
\text { Squar } \\
\mathrm{e}\end{array}$ & $\begin{array}{l}\text { Adjusted } \\
\text { R Square }\end{array}$ & $\begin{array}{l}\text { Std. Error } \\
\text { of the } \\
\text { Estimate }\end{array}$ & $\begin{array}{l}\text { Durbin- } \\
\text { Watson }\end{array}$ \\
\hline 1 &, $735^{a}$ &, 540 &, 506 &, 161372 & 1,721 \\
\hline
\end{tabular}

a. Predictors: (Constant), Lag_SIZE, Lag_ROA, Lag_CAR

b. Dependent Variable: FDR

Sumber : Hasil Uji SPSS 18 (Data Diolah)

Berdasarkan Tabel 4.7 hasil Uji DurbinWatson pada penelitian ini mempunyai 
Prakoso, et al/Jurnal Ekonomi Syariah Teori dan Terapan Vol. 4 No. 11 November 2017: 860-874; DETERMINAN FINANCING TO DEPOSIT RATIO BANK UMUM SYARIAH DI INDONESIA PERIODE 2012 - 2015

nilai 2,185 dengan $\mathrm{K}$ sebanyak 5 (Jumlah variabel independen) dan $\mathrm{N}$ sebanyak 44 (Jumlah Sampel). Maka nilai DW berada pada $1,65<1,721<2,35$, maka dalam penelitian ini disimpulkan tidak ada autokorelasi.

\section{Uji Normalitas}

Uji Normalitas bertujuan untuk menguji dalam model regresi, variabel eksogen dan endogen. Apabila uji ini tidak memenuhi asumsi maka uji statistik menjadi tidak valid. Cara untuk menguji normalitas data yaitu dengan analisis grafik P-Plot.

Analisis statistik yang dapat digunakan untuk menguji normalitas adalah uji non parametrik Kolmogrov-smirnov. Data yang disebut terdistribusi dengan normal jika siginifikasi (2-tailed) menunjukan lebih dari 0,05 .

Tabel 4.4

Hasil Uji Kolmogorov-Smirnov

One-Sample Kolmogorov-Smirnov Test

\begin{tabular}{|c|c|c|}
\hline & & $\begin{array}{c}\text { Unstandar } \\
\text { dized } \\
\text { Residual }\end{array}$ \\
\hline \multicolumn{2}{|l|}{$N$} & 44 \\
\hline \multirow{2}{*}{$\begin{array}{l}\text { Normal } \\
\text { Parameters } a, b\end{array}$} & Mean & ,0000000 \\
\hline & Std. Deviation & , 15564137 \\
\hline \multirow{2}{*}{$\begin{array}{l}\text { Most Extreme } \\
\text { Differences }\end{array}$} & Absolute & , 103 \\
\hline & $\begin{array}{l}\text { Positive } \\
\text { Negative }\end{array}$ & $\begin{array}{r}, 103 \\
-, 100\end{array}$ \\
\hline \multicolumn{2}{|c|}{ Kolmogorov-Smirnov Z } & ,682 \\
\hline \multicolumn{2}{|c|}{ Asymp. Sig. (2-tailed) } & ,741 \\
\hline
\end{tabular}

a. Test distribution is Normal.

b. Calculated from data.

Sumber : Hasil Uji SPSS 18 (Data Diolah)

Berdasarkan Tabel 4.4 dapat diketahui bahwa nilai yang dihasilkan dalam uji Kolmogorov-smirnov adalah sebesar 0,682 dengan tingkat signifikansi sebesar 0,741.
Hal ini menunjukan bahwa dalam penelitian ini data telah terdistribusi dengan normal dan lolos dalam uji normalitas.

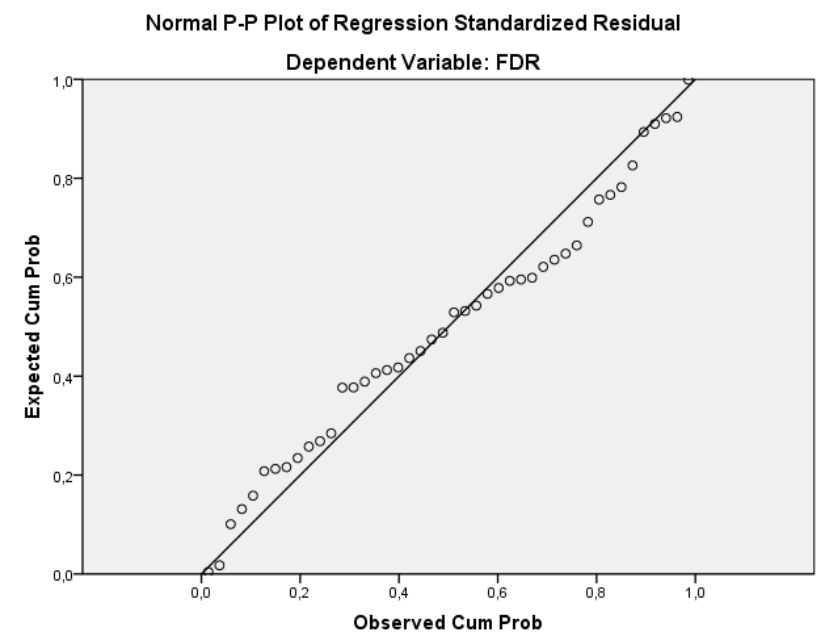

Sumber : Hasil Uji SPSS 18 (Data Diolah)

Gambar 4.2

Grafik Normalitas P-Plot

Berdasarkan Gambar 4.2 terlihat bahwa data menyebar di sekitar garis diagonal dan mengikuti arah garis tersebut. Maka dapat disimpulkan Grafik P-Plot telah memperlihatkan data dalam penelitian in secara normal.

\section{Pembahasan}

\section{Pengaruh CAR terhadap FDR Bank Umum} Syariah di Indonesia

Berdasarkan hasil penelitan ini diketahui bahwa Capital Adequcy Ratio (CAR) berpengaruh signifikan positif terhadap Financing to Deposit Ratio (FDR), hal ini ditunjukkan dengan Nilai $t$ hitung yang ditunjukkan oleh variabel CAR sebesar 6.727 dan nilai t tabel sebesar 2.021075. sehingga dapat disimpulkan bahwa Capital Adequcy Ratio (CAR) memiliki pengaruh positif signifikan terhadap 
Financing to Deposit Ratio (FDR) dan $\mathrm{H}_{1}$ diterima.

Hasil penelitian ini mendukung penelitian yang dilakukan oleh Parinsi (2015) yang mengatakan variabel Capital Adequacy Ratio (CAR) berpengaruh positif signifikan terhadap LDR. Hal tersebut juga dibuktikan oleh penelitian yang dilakukan oleh Ervina (2015) yang menyatakan bahwa Capital Adequacy Ratio (CAR) berpengaruh terhadap FDR pada KJKS-BMT. Hal sama juga dilakukan oleh penelitan yang dilakukan oleh Abdillah (2016) membuktikan bahwa CAR berpengaruh positif signifikan terhadap FDR bank di Indonesia.

Rasio kecukupan modal minimum yang harus ada pada setiap bank sebagai pengembangan usaha dan menampung risiko kerugian usaha bank, merupakan pembagian dari modal dengan total Aktiva Tertimbang Menurut Risiko. Berdasarkan ketentuan Bank Indonesia, bank dinyatakan termasuk sebagai bank yang sehat harus memiliki CAR paling sedikit adalah $8 \%$. Hal ini didasarkan pada ketentuan yang ditetapkan oleh Bank Indonesia sebagai standar tingkat kesehatan bank untuk permodalan. Bank yang memiliki CAR yang tinggi maka pembiayaannya juga banyak, sehingga apabila CAR meningkat maka akan meningkatkan FDR.

Pengaruh ROA terhadap FDR Bank Umum Syariah di indonesia

Berdasarkan hasil penelitan ini diketahui bahwa Return On Assets (ROA) berpengaruh signifikan negatif terhadap
Financing to Deposit Ratio (FDR), hal ini ditunjukkan dengan nilai $t$ hitung lebih besar dari t tabel yakni -2.831 > 2.021075 (Lampiran Tabel T), dengan tingkat signifikannya sebesar 0.007 lebih kecil dari 0.05, sehingga dapat disimpulkan bahwa Return On Assets (ROA) memiliki pengaruh negatif signifikan terhadap Financing to Deposit Ratio (FDR) dan $\mathrm{H}_{1}$ diterima.

Hasil penelitian ini didukung penelitian yang dilakukan oleh Solekah (2015) yang menyatakan bahwa Return On Assets (ROA) berpengaruh negatif dan signifikan terhadap Financing to Deposit Ratio (FDR). Hal yang sama juga dibuktikan oleh Ervina (2015) yang menyatakan bahwa Return On Assets (ROA) berpengaruh negatif signifikan terhadap Financing to Deposit Ratio (FDR). Sedangkan hal tersebut juga dibuktikan oleh Moussa (2015) bahwa ROA berpengaruh negatif signifikan terhadap Financing to Deposit Ratio

ROA merupakan refleksi tingkat profitabilitas suatu bank. Jika ROA semakin besar maka semakin besar pula tingkat keuntungan yang diperoleh bank, dengan laba yang besar akan meningkatkan aset sehingga bank dapat menyalurkan kredit lebih banyak dan dapat memenuhi kewajiban jangka pendeknya. Tetapi dalam hasil penelitian dalam periode ini terdapat hasil yang bertolak belakang dari pernyataan tersebut. Peningkatan ROA pada tahun sebelumnya justru tidak membuat BUS untuk meningkatkan kegiatan intermediary-nya sebagai penyalur pembiayaan. Hal ini dikarenakan 
pembiayaan yang disalurkan oleh BUS pada periode penelitian tidak banyak memberikan kontribusi laba karena pada tahun tersebut terdapat gap yang tinggi antara bank-bank yang beroperasi pada saat itu dalam mengucurkan pembiayaan.

\section{Pengaruh Size terhadap FDR Bank Umum Syariah di Indonesia}

Berdasarkan hasil penelitan ini diketahui bahwa size berpengaruh signifikan terhadap Financing to Deposit Ratio (FDR), hal ini ditunjukkan dengan nilai † hitung lebih kecil dari $t$ tabel yakni $2.564<$ 2.021075, dengan tingkat signifikannya sebesar 0.014 lebih kecil dari 0.05, sehingga dapat disimpulkan bahwa Size memiliki pengaruh positif signifikan terhadap Financing to Deposit Ratio (FDR) dan $\mathrm{H}_{1}$ diterima.

Hasil penelitian ini didukung penelitian yang dilakukan oleh Santoso dan Tekad (2012) yang membuktikan juga bahwa variabel size berpengaruh positif dan signifikan terhadap Financing to Deposit Ratio (FDR) dan didukung oleh penelitian Bramantya (2015) yang menyatakan bahwa Size berpengaruh positif terhadap Financing to Deposit Ratio (FDR) pada Bank Umum yang terdaftar di Bursa Efek Indonesia.

Struktur aset sangat berpengaruh terhadap besarnya laba yang dihasilkan. Apabila porsi terbesar aset adalah piutang dari penyaluran kredit, maka piutang dari penyaluran kredit (kategori lancar atau performing loans) akan meningkatkan pendapatan yang diterima karena performing loans ini merupakan income-generating asset dalam bentuk pendapatan operasional (Wild dkk. 2010). Dalam hal ini dapat disimpulkan bahwa jika variabl Size pada tahun sebelumnya meningkat maka akan mempengaruhi peningkatan pembiayaan pada variabel FDR pada tahun tertentu.

\section{Kesimpulan}

Berdasarkan penelitian yang telah dilakukan, maka dapat diambil keputusan sebagai berikut:

1. Variabel Capital Adequacy ratio (CAR) secara parsial memiliki pengaruh positif signifikan terhadap Financing to Deposit Ratio (FDR) Bank Umum Syariah di Indonesia pada periode tahun 2012 2015 dengan $\dagger$ hitung $>$ † tabel yakni $6.727>2.021075$.

2. Variabel Return On Assets (ROA) secara parsial memiliki pengaruh negatif signifikan terhadap Financing to Deposit Ratio (FDR) Bank Umum Syariah di Indonesia pada periode tahun 2012 2015 dengan $†$ hitung $>$ † tabel yakni $2.831>2.021075$.

3. Variabel Size secara parsial memiliki pengaruh signifikan positif terhadap Financing to Deposit Ratio (FDR) Bank Umum Syariah di Indonesia pada periode tahun 2012 - 2015 dengan $\dagger$ hitung > t tabel yakni $2.564>2.021075$.

4. Jumlah Capital Adequacy Ratio (CAR), Return On Assets (ROA), Size berpengaruh signifikan Financing to Deposit Ratio (FDR) dengan $F$ hitung lebih besar dari pada F Tabel $15.664>$ 
Prakoso, et al/Jurnal Ekonomi Syariah Teori dan Terapan Vol. 4 No. 11 November 2017: 860-874; DETERMINAN FINANCING TO DEPOSIT RATIO BANK UMUM SYARIAH DI INDONESIA PERIODE 2012 - 2015

2.838745 dan tingkat signifikan $0.000<$ 0.05 .

\section{Daftar Pustaka}

Abdillah, Rahmat, Dkk. 2016. The Determinants Factor Of Islamic Bank's Profitability And Liquidity In Indonesia. Knowledge Horizons - Economics. Vol 8 No. 2

Ali, Zainuddin. 2008. Hukum Perbankan Syariah. Jakarta: Sinar Grafika

Antonio, Muhammad Syafi'i. 2001. Bank Syariah Dari Teori ke Praktik. Jakarta: Gema Insani.

Bramantya, Bintang. 2015. Analisis Pengaruh Size, Profitability, Capital Adequacy, Dan Non-Performing Loan Terhadap Likuiditas Bank Umum Yang Terdaftar Di Bursa Efek Indonesia Periode 2011-2014. Skripsi. Universitas Diponegoro.

Brigham, Eugene dan Joel F Houston, 2001. Manajemen Keuangan II. Jakarta:Salemba Empat

Dendawijaya, Lukman. 2005. Manajemen Perbankan. Jakarta:Ghalialndah

Edo, Delsy Setiawan dan Ni Luh Putu. 2014. Pengaruh Dana Pihak Ketiga, Non Performing Loan, Dan Capital Adequacy Ratio Terhadap Loan To Deposit Ratio Dan Return On Assets Pada Sektor Perbankan Di Bursa Efek Indonesia. E-Jurnal Ekonomi dan Bisnis Universitas Udayana. Volume 3.11

Ervina. 2015. Pengaruh Dana Pihak Ketiga (DPK), Non Performing Financing (NPF), Capital Adequacy Ratio (CAR), dan Return On Asset (ROA) Terhadap
Tingkat Likuiditas Koperasi Jasa Kevangan Syariah Baitul Maal Wat Tamwil (KJKS-BMT).Jurnal Universitas Negeri Semarang di Akses 28 November 2016

Ervina. 2015. Pengaruh Dana Pihak Ketiga (DPK), Non Performing Financing (NPF), Capital Adequacy Ratio (CAR), dan Return On Asset (ROA) Terhadap Tingkat Likuiditas Koperasi Jasa Kevangan Syariah Baitul Maal Wat Tamwil (KJKS-BMT).Jurnal Universitas Negeri Semarang di Akses 28 November 2016

Ismail. 2011. Perbankan Syariah. Jakarta: Kencana Prenada Media Group.

Ismal, Rifki. 2010,"Assessment of liquidity management in Islamic banking industry", International Journal of Islamic and Middle Eastern Finance and Management, Vol. 3 Iss 2 pp. 147 - 167

Kasmir .2012. Analisis Laporan Keuangan.Jakarta: Salemba Empat.

Kasmir. 2002. Bank dan Lembaga Keuangan Lainnya edisi keenam. Jakarta: PT Raja Grafindo Persada.

Moussa, Mohamed Aymen. 2015. The Determinants of Bank Liquidity: Case of Tunisia.International Journal of Economics and Financial Issues Vol 5 , No. 1

Munandar, Eris. 2009. Pengaruh Dana Pihak Ketiga, Loan to Deposit Ratio dan Return On Asset Terhadap Pembiayaan Pada Bank Syariah Mandiri. Yogyakarta: Universitas Islam Negeri Sunan Kalijaga. 
Parinsi, Elvira M.C. 2013. Analisis Pengaruh CAR, NPL, NIM dan ROA Terhadap Likuiditas Pada Bank BUMN (Persero) Di Indonesia Periode 2007-2011. Skripsi. Universitas Hasanuddin. Diakses 11 Januari 2017

Rivai, Veitzhal. 2007. "Bank and Financial Institution Management, Conventional \& Sharia System". Jakarta: PT Raja Grafindo Persada

Santoso, Arif Lukman dan Tekad Sukihanjani. 2012. Analisis Faktor-Faktor Yang Mempengaruhi Likuiditas Perbankan Di Indonesia. Jurnal Universitas Sebelas Maret.

Solekah, Elsa Almar'atus. 2015. Pengaruh Non Performing Finance, Capital Adequacy Ratio, Return On Asset dan Inflasi Terhadap Financial to Deposit Ratio Pada Bank Pembiayaan Rakyat Syariah Di Indonesia. Tulungagung : Skripsi. IAIN Tulunagung

Sujianto, Agus Eko. 2009. Aplikasi Statistik dengan SPSS 16.0. Jakarta: Prestasi Pustaka Publisher.

Taswan. 2006. Manajemen Perbankan

(Konsep, Teknis \& Aplikasi). Yogyakarta: UPP STIM YKPN

Utari, Mita Puji. 2011. Analisis Pengaruh CAR, NPL, ROA, dan BOPO terhadap LDR. Skripsi Universitas Diponegoro. http://papers.gunadarma.ac.id/

Diakses tanggal 27 Desember 2016.

Wild, J.J., Subramanyam, K.R., dan Halsey, R.F,. 2010. Analisis Laporan Kevangan. Edisi 10. Salemba Empat: Jakarta. 